\title{
Transcendental Epistemology Study of Philosophy of Wisdom Muta'aliyah Mulla Sadra
}

\author{
Fauziah Nurdin ${ }^{1}$, Hasymsyah Nasution ${ }^{2}$, Hasan Bakti Nasution ${ }^{3}$ \\ ${ }^{1} \mathrm{Ph} . \mathrm{D}$ Student in State Islamic University of North Sumatera (UINSU), Medan, Indonesia \\ ${ }^{2}$ Lecturer in State Islamic University of North Sumatera (UINSU), Medan, Indonesia \\ fauziahnurdin@gmail.com
}

\begin{abstract}
The aim of the study is to find out Transcendental Epistemology by using Muta'aliyah Mulla Sadra. This study used qualitative research methodology. The result of the study is Mullâ Shadrâ system is different from the emphasis on specific aspects of "rationality" as it is now does not mean that its founder understands it as "irrational" nor is it given to "mystical experience". But the system emphasizes a world view that intuitive vision is an inseparable part of knowledge. With this method, knowledge or wisdom is obtained not only that is generated by the power of reason but also through spiritual enlightenment, and all of that is then presented in rational form using rational arguments. For Mullâ Shadrâ, knowledge or wisdom is not only to enlighten cognition but also realization; change the form of the recipient of enlightenment itself and realize the knowledge gained so that the transformation of form occurs. All that cannot be achieved except by following the Shari'a, so a thought must hook the infant method in its system.
\end{abstract}

Keywods: Transcendental; epistemology; muta'aliyah; mulla sadra.

\section{Introduction}

Epistemology or scientific theory is a very vital study in human civilization, because it discusses a very fundamental aspect of human life, namely science. Epistemology examines philosophically the origin, structure, methods, validity and purpose of science. He explained the so-called truth and criteria and explained ways that could help obtain that truth. Epistemology has a fairly central place in the building of philosophy of science, so that epistemology has attracted the attention of thinkers both in the West and in the building of modern Islamic thought.

The dynamics of epistemology in religious thought in the Islamic world have been going on since the classical period (650-1250), the middle period (1250-1800) and the modern period (1800-present). The period of the development of modern thought as the third period is seen as the period of the revival of Muslims after sinking during the middle Ages. However, the presence of modernism has led to diverse responses and led to tensions among Muslims. With the modernization in all fields in several countries, like Egypt entering the liberal age (liberal age). The understanding of liberalism blossomed which resulted in the emergence of a number of ideas about the separation between religion, culture and politics. With the development of liberative understanding in Egypt, what was called an-nahdah (renaissance) was born, which then gave birth to several trends of thought:

(1) This trend of thinking towards traditionalism is called The Islamic Trend (tendency towards Islam). This view began with the teachings of Ibn Hanbal who experienced the ultimate success through Muhammad ibn Abd al-Wahhab (1703-1992).

(2) The Syntetic and The Rational Scientific and Liberal Trend (a rational synthesis of scientific and free thinking), a group that seeks to integrate Islam and Western culture. This group was represented by Qâsim Amîn (1865-1908), and 'Ali' Abd. ar-Ra'qq (1888-1966), Tâha Husein (1883-1973), Lutfî as-Sayyid (1872-1972), Zakî Najîb Mahmûd (1905-1993), Salamah Mûsa, Farag Fawdah, Fu'ad Zakariya, Hassan Hanafî 
(1875-1972) 1935), Mohammed Arkoun, Muhammad Syahrur, Seyyed Hosein Nasr and Nasr Hâmid Abû Zaid.

Epistemology, which has grown since hundreds of years ago, is now in a position of increasingly exciting development. The presence of universities in various parts of the world, including in Indonesia in accordance with its main function to develop science, has made a significant contribution in maintaining the spirit of scientific development. Various findings in the fields of science, technology and art have helped enrich intellectual property, while at the same time making important contributions to human life.

Almost all disciplines that are currently developing both in the world of education and in the environment of its users, basically originated from the ideas of the initiators or discoverers. They have contributed greatly to the process of cultural transformation of the world community. Information of the initiators and discoverers of theories that have enriched the knowledge is now scattered in a variety of literature, especially relating to the history of the development of a science. The development of science, both within educational institutions and within the scope of its utilization in the practical world, always opens opportunities to be explored, criticized, or even refuted in accordance with the different perspectives it uses. However, philosophically, the growth and development of science will in turn lead to themes of humanity, nature, and divinity. Science then emerged and developed as an answer to various questions around these three themes.

In the perspective of Islamic epistemology, there is no known dichotomy between religious science and non-religious (general) science. Science is science; it comes from the same source, then develops according to the area of each object, both regarding material objects and form objects. He continues to come in contact with natural phenomena, humans and anything that is outside of both. It is through contact that knowledge continues to develop into historical space from time to time

\section{Review of Literature}

\subsection{Biography, Education and Works}

Mullâ Shadrâ was born in Shiraz in 1572 AD His full name is Muhammad bin Ibrahim Yahya Qawami Shirazi, often called by the nickname Sadruddin Asy-Syirazi or Mulla Sadra or Sadra. Among his students, he was better known as Shadr Al-Muta'allihin. He was named by the nickname because of the height of his knowledge of Wisdom. or often called Sadr alDin al-Shirazi or Akhun Mulla Sadra. He was born in Shiraz, the most famous city in Iran, around Persepolis in 979/980 H or 1571/1572 AD His father was Ibrahim ibn Yahya, and his father was a respected aristocrat in the city. His father was once the governor of the Fars region. His social status and as an only child, he had the opportunity to get a good education and perfect care in his hometown. As an intelligent child, he is able to quickly master a variety of subjects taught to him. At a young age, Mullâ Shadrâ continued his studies to Isfahan, an important cultural center for the Eastern Islamic world at the time, he studied with the theologian Baha 'al-Din al-'Amili (d. $1031 \mathrm{H} / 1622$ AD), then to philosophers Peripatetic Mir Abu al-Qasm Fendereski (d. $1050 \mathrm{H}$ / 1641). But his most important teacher was a philosopher-theologian named Muhammad or better known as Mir Damad (d. $1041 \mathrm{~h} / 1631$ AD), who was the originator of the founding center of philosophical and theological studies which is now known as the "Isfahan school". 
Mulla Sadra is a figure who with his personal potential and supported by the formation of the intellectual tradition of his day succeeded in taking the accumulation of knowledge traditions that developed in his day and also in previous periods. He as mentioned by his admirers is not merely adopting and synthesizing existing ideas, but he has done more than that by giving a new value and format to an intellectual tendency. According to Fazlur Rahman, "This synthesis was not solely produced by superficial 'reconciliation' and 'compromise', but based on philosophical principles that were put forward and explained for the first time in Islamic history.

\subsection{Basic Epistemology of Mullâ Sadad}

The Muta'aliyah Wisdom is a new series of processes to perfect the Islamic epistemology and can even be considered as the high point of its journey. This is because the wisdom of muta'aliyah; good kalam, philosophy, irfan, along with the sacred texts united to produce a new epistemology and new alternative thoughts called muta'aliyah wisdom. Therefore the renewal of the Islamic epistemology presented by Mull Shadr is greatly supported by the approach and methodology used. In reaching the reality of reality it takes a contemplative effort, both contemplation through riyadhah or purification of self and mysticism through the mind from the potential sense to the mustafad sense until it merges with the active mind.

According to Mulla Sadr, the inability of some philosophers to solve some epistemological problems is not only because they do not purify the soul, but also because they leave more time in particular sciences. Another opportunity, Mullâ Shadrâ, also believes that it is not enough to rely solely on the shuhûd alone in revealing the true nature of reality because to achieve perfect disclosure would require an argument or a reason of pure reason. In addition, the position of burhan or argumentation for Mullâ Shadrâ is the best language in explaining syuhûd and mukâsyafah. The ambiguity of urafa in explaining their experiences is evidence of their inability to express syuhûd and mukâsyafah, and that is because urafa does not undergo intellectual miracle.

Mullâ Shadrâ also followed the previous philosophers that the method of syuhûd was higher than the method of burhan or argumentation, but according to him it must be admitted that the method of riyadhah and jihadun nafs was a very difficult method and only a few were able to reach the intended goal, because this method was the challenge so much that it is possible for humans to fall into error.

\subsection{Mullâ Shadrâ Epistemological Construction}

In Mullâ Shadrâ epistemology, the Qur'an is the main way to reach essential knowledge. The scriptures for Mullâ Shadrâ are sources of philosophical and philosophical inspiration that cannot be replaced by other books. Mullâ Shadrâ judges the Koran by itself. Being, like al-Qur'an, has letters (letters) which are the "keys to the unseen world" and from the combination of letters a verse is formed and from the verses the verses of the Scriptures are arranged. Furthermore, from the combination of the surah is produced "book of being" which manifests itself in two ways: as al-furqon or differentiator, and al-Qur'an or reading (both of these terms are the names of the Qur'an).

The furqani aspect of the holy book is the macrocosm with all its diversity, while the Quran aspect is the spiritual reality of human archetypes or commonly called universal / perfect humans (al-insan al-kamil). Therefore, the keys (mafatih) to the unseen world, insofar 
as the Qur'anic revelations are examined, are also key keys to understanding the invisible dimensions of the world of external existence and the inner form of human beings and vice versa. Regarding reason as a source of knowledge, Mullâ Shadrâ believes that the mind in the mind is a reflection of the shadow of the universal mind in the human soul, is a kind of prophet or human guide to the divine message, which is if the person understands the content of the Qur'an deeply.

In this case he distinguishes reason into four levels: the potential of reason (al-'aql bi al-quwwah), possessive reason (al-'aql bi al-malakah), actual reason (al-'aql bi al-fi'l), and reason obtained (al'aql bi almustafad). ${ }^{l}$ At the level of potential reason (al-qaql bi alquwwah) is included in the soul from the beginning and as the soul itself, has no proof of itself, and speculative understandings. This condition of the existence of the soul is the last stage in the physical realm and the first stage to enter the realm of metaphysics. The level of possessive reason (al-qaql bi al-malakah) occurs right after the previous one, actualized through the acquisition of primary understandings (concepts and agreements) or primary data, data through experiments, data through transmission, etc. (the same for everyone) such as "the whole is greater than the parts", "lying is not a good deed", one is half of two ", and so on.

These perceptions are needed to actualize the next level. The third level is actual reason (al- 'aql bi al-fi'l). When these understandings are moved towards the soul, then reflection and longing to conclude understandings that have not been understood will emerge in humans, which in turn will make him voluntarily contemplate using what he previously had to gain new mental understanding. Although speculative intellectual understandings do not actually come together with reason, they will be understood as soon as the soul wants to do it, and there will be no search for evidence and thought moves (towards what is understood, then from what is understood to something that is not understood); because of this frequent observation of speculative and intellectual understanding, the intellectual movement towards so many principles, and related to them, has led to a relationship of ownership and understanding of reason, and therefore, will actually be present with it.

The fourth level, reason obtained (al-'aql bi al-mustafad). This level is exactly the same as actual reason except that all speculative understanding is actually present with it, and does not require willingness and attention. The reason is that the soul seeks all proof of itself and all forms of speculative understanding, which correspond to the higher or lower truths, without any material intermediary at the time it is associated with active Intellect (al-'Aql al$\mathrm{fa}^{\prime} \mathrm{al}$ ) and, therefore, such an intellectual world is the same as objective nature. That is why such reason is called acquired: because the benefit it receives comes from outside, that is, active reason. ${ }^{2}$ From this point of view man is a perfection of a place back, just as active reason is a perfection and an end to nature which is the beginning; because the peak of the creation of material nature is human creation and the peak of human creation is the stage of reason obtained, namely the search for a stage of understanding and relationship to the higher realms. Furthermore Mullâ Shadrâ fully believes that the most successful method for attaining true knowledge is kasyf, which is supported by revelation, and does not conflict with the burhan.

239 Ibid., p. 138. 


\section{Discussion}

\subsection{Muta'aliyah (The Transcendent Theosophy) Epistemology}

This book is considered the peak and most important work of Mullâ Shadrâ. In the opening of this book, he wrote a kind of "intellectual autobiography" that underlies his birth. There, Mullâ Shadrâ said: he had studied "al-falsafa al-Ilahiyya", the philosophy of God, from a very young age (al-hadatha wa al-ra'ian). At some point, he seemed to experience frustration with the knowledge he had been studying, because the intellectual environment around him showed hostility towards him. As we know, philosophy is indeed a field of knowledge that is often suspected by Islamic scholars, especially those who are traditional sciences. Intellectual atmosphere that hates this philosophy makes Mullâ Shadrâ do "selfisolation" by moving away from the crowd. He meditated for years, while still deepening the knowledge he had gained so far. Meanwhile, he not only deepened intellectually, but also underwent a kind of "mental exercise" by cleansing the heart of all impurities and practicing worship solemnly. Over the years he underwent this self-isolation, until he came to a point where he experienced a kind of illumination (isyraq), a kind of "aha moment" - he experienced a "stasis" or spiritual state in which the sciences he originally acquired through the rational proof method of the "burhan" (demonstrative) model, now reinforced through "musyahada" or spiritual experience.

Mullâ Shadrâ experience is somewhat similar to that experienced by al-Ghazali, an important scholar from the Sunni world. Like Mullâ Shadrâ, al-Ghazali had committed selfisolation, meditated for years, lived the life of the mystics or mutasawwifin. At the end of this process of self-exclusion, both Mullâ Shadrâ or al-Ghazali experienced an almost similar situation, namely the disclosure that made them both witness true knowledge, not knowledge learned through rational or burhan methods. For these two great Muslim scholars and philosophers, the intuitive method is a more reliable way to attain true knowledge (al-haqq).

The difference between al-Ghazali and Mullâ Shadrâ is in the following: al-Ghazali, after arriving at the intuitive experience, did not write philosophical works; instead he uses the intuitive method to emphasize the supremacy of orthodoxy of traditional sciences, especially sharia. We can see this in his monumental work Ihya 'Ulum al-Din. Meanwhile, Mullâ Shadrâ, took another route. After reaching that stage of intuitive knowledge, he built a philosophical system that combines various pre-existing philosophical traditions. In other words, Mullâ Shadrâ used that intuitive method to build his own philosophical system. If in al-Ghazali what is called the zawq and kasyaf method or intuition and illumination is only an individual experience experienced through acts of worship, in Mullâ Shadrâ, that method is a way to achieve a specific substance of knowledge, namely knowledge which he later referred to as "Al-hikmah al-muta'aliyah".

The full title of this work is Al-Hikmah al-Muta'aliyah fi al-Asfar al-qAqliyya alArba'a - Transcendent Philosophy, about the journey of reason which is four levels. This title immediately reminds us of a book written by a scholastic theologian from Italy who lived in the 13th century, St. Bonaventure (d. 1274). The book is Itinerarium Mentis in Deum (Soul Journey to God). The metaphor of "travel", itinerarium or, in Islamic mystical terms, suluk, is indeed often used by mystical practitioners of various religious traditions. Mullâ Shadrâ, in this work, uses the term safar which means nothing but travel, spiritual adventure.

There are four types of spiritual / intellectual adventures reviewed by Mullâ Shadrâ through this book: 1) the journey from the world of creation (al-khalq), the visible world, 
towards the world of creators, the world of true truth (al-Haqq). This journey is taken by means of a kind of "empirical observation" of natural phenomena. Through observation of the diverse world of order, reason to something that unites diversity. You name it, this is the spiritual empiricism of Mullâ Shadrâ style. 2) Journey in true truth (al-Haqq) through true knowledge. This is the phase of transcendence: the stage of transcending the diversity of natural nature, and sinking into the Absolute Oneness which does not concern accidental diversity ('aradl). 3) The journey from the Truthful to the world of creation, through true knowledge obtained in the second stage above. This is the second empiricism that has undergone a radical transformation. Therefore, diversity is seen not as diversity in itself, but as a manifestation of Absolute Oneness.4) A journey together with the Truthful in the world of creation.

The difference between the fourth and third stages is: in the 3rd stage, what we encounter is a journey to (ila) to the world of creation, while in the fourth stage, we encounter a journey in $(f i)$ the world of creation itself. In other words, at this fourth stage there is the peak of adventure, where the mind sinks in the realm of creation, but sees it with true science (al-Haqq). Intellect is part of the world, but it is also at a distance from the world. This fourth stage ambiguity explains briefly a kind of "cosmology" and "ontology". The synthesis of thought conducted by Sadra is based on three ways of knowing as mentioned above which then leads to a "world view" and creates a new intellectual point of view which known as AlHikmah Al-Muta'aliyah (Transcendental Theosophy). Even though this term actually already exists and was mentioned by figures before Sadra, but he is considered a figure that formulated systematically and made it a school of theosophy. He was so faithful to use the term that a book that systematically discussed the basics of his mystical philosophy was given the title "Al-Hikmah Al-Muta'aliyah Fi Al-Asfar Al-Aqliyah Al-Arba'ah".

\subsection{Sadra's Epistemology about God}

Based on the line of thought above, Mullâ Shadrâ idea of God is different from the idea of divinity possessed by Al-Farabi and Ibn Sina. Their idea of God rests on the perception of the "inevitability of existence" and according to them too, introducing God is not enough to peg the understanding of the qadim-ness and the benchmarks of the essential and perfection of God. In their view, the difference between Mandatory Being and contingent being is that contingent forms are captured and are composed of quiddity and existence, while Mandatory Being is a pure form and is not composed of quiddity. Because the form itself is at the level of God's essence and is not additional to His essence, then His substance at that level is inseparable from the form so it must be needed at that form.

Mullâ Shadrâ argues that the unity and perfection of God's essence is not enough to emphasize the essence and oneness of God's essence and existence. In his view, the theory that God is a pure form and basith is not the postulate of the inevitability and absolute necessity of God, this theory is nothing but asserted that the assumed existence is an actual existence and not an actual formation. The condition of the inevitability of a being is reality and the necessity for cause. So, a perfect introduction to the essence of God must include both conditions of necessity. In the metaphysical system of wisdom muta'aliyah, resting on the theory of the reality of existence (ashâlah al-wujud), the form of God is affirmed as a form of infinite high intensity and creature is a form of low intensity, need and impossible to be the cause of presence for itself, therefore he must depend on the Absolute Being. 
Essential existence only belongs to God. His form is unlimited and has essential independence. The independence of God in the dimensions of matter and His nature, this means that He does not depend on other realities, He was not created from other realities and nothing but He can destroy Him. Only God is tangible, the Rich, Perfect and unlimited. His form is unconditional and $\mathrm{He}$ is an absolute condition for the realization of other realities. Thus, simplicity has a deep understanding of God's form which is impossible to negate one of the perfections that He must have. Mullâ Shadrâ assumes that God has absolute perfection and His essence is inherently integrated with His nature. The difference between God and creature is not understood as two realities that have boundaries and dividing lines, but the difference between them lies in the perfection of God and the lack of creatures, His strengths and weaknesses. Therefore, the difference between the two is not face to face differences but differences that are "encompassing" and "covers". In other words, all forms besides Him are a series of gradations of the manifestation of His essential light and nature and not as realities that are independent and essentially separate from His existence. Unity of being and existence as a whole and essential in the reality of the plurality of both. According to Mullâ Shadrâ, such understanding of monotheism is the highest level of monotheism possessed by true monotheists from 'urafa and hukama muta'aliyah.

God's unity is not a mathematical number. This idea is a brilliant thought of Islamic philosophy that is not shared by any school of philosophy. This brilliant theory is inseparable from the mutual influence between the doctrines of the Islamic holy teachings and the contemplative study of Islamic philosophy. Believes that God is an essential unity. This perception is the most basic principle in the wisdom of Muta'aliyah and also the basis of philosophical thinking after Mullâ Shadrâ. We have not found this idea in the thinking of Islamic philosophers before Mullâ Shadrâ like Al-Farabi and Ibn Sina. The philosophers who put these ideas into their philosophy then named the unity as al-hakkah al-hakikiyyah, and in tasawuf (irfan) the unity was called al-wahdah al-wujud (unity of being). This unity means that God is an absolute form and absolute form.

\subsection{Epistemology about the Soul}

The soul is not eternal, in the sense that it starts, it cannot be separated and free from matter. Aristotle defines the soul as the entelechy of the body. Al-Farabi explicitly identifies the human soul as a faculty or power inherent in the body and not as a spiritual substance that can exist independently of the body. For Ibn Sina, the human soul, although only a potential intellect at the beginning of his career, but he is an immaterial spiritual substance that can exist independently of the body. According to Mullâ Shadrâ, the soul is a physical body entelechy that works through faculties called organs. What is meant by organs according to Mullâ Shadrâ is not physical organs such as hands, stomach, and so on, but faculties or resources with which the soul can work, such as appetite, nutrition and digestion.

Mullâ Shadrâ rejects Ibn Sina's view which states that the soul is a relational concept and not something substantive. If the soul is born in matter, the soul cannot be interpreted as a relation where as if the soul has a free existence then it is related to matter. After all, if the human soul is a free substance, then it is not possible to unite the soul with the body. The relationship between the soul and the body is not like the relationship between ordinary physical force and its material. The soul works in matter through the link in the form of the forces beneath it. 
According to Mullâ Shadrâ the soul rests on a basic principle called substantive change (istihalajauhariya). In general, the soul is physical, but ultimately it is spiritual forever (jimaniyat al-huduts ruhaniyat al-baqa '). That is, when the soul arises on a material basis, it does not mean that the soul is absolutely material. With this principle of substantive change, a higher level of ground is required. Therefore, even in the lowest life, such as plants, even though it depends on matter, it cannot be said to be entirely material. Material or body is only an instrument and is the first step to move from the material world to the spiritual realm.

\section{Conclusion}

Epistemology is the center of every view, it becomes a parameter that determines what might be known and must be known, what is possible but better avoided and what is totally unknown. In defining epistemology is trying to find out knowledge, mark sources, distinguish variations, and determine the limits.

In Islam, to obtain knowledge is not only based on reason and senses, but also based on revelation. Muslim thinkers agree that the power of reason or rationalism is very necessary in religious studies. But the extent to which the ability of the ratio can be followed and used, this is the problem. Some states that the ratio must be placed under the revelation, while others consider that the ratio alone is sufficient to guide humans in knowing the truth and God, revelation is needed only as a justification for the discovery of reason.

In connection with this, three schools of epistemology emerge in Islam, namely bayani, irfani, and burhani. With regard to the epistemological features of Mullâ Shadrâ, it will be even clearer when compared with the epistemological models in Islamic thought. Through this comparison. can be seen the uniqueness of Mullâ Shadrâ thought among the epistemology that preceded it. Thus, it is no exaggeration and is not without reason if it is said that this epistemology is indeed something new in the intellectual realm of Islam. If it is associated with the infant epistemology, it is found that there is a close connection between the two, namely each rests on the text. al-Qur'an and Hadith are the main sources of knowledge in the epistemology of bayani and in the epistemology of Mullâ Shadrâ. Mullâ Shadrâ epistemology is inseparable from the irfani method, even Mullâ Shadrâ states that the irfani method is the most successful method for achieving essential knowledge. Mullâ Shadrâ epistemology also requires knowledge of the burhan, knowledge obtained through kasyf is impossible to explain to others except by using the burhan method. Thus the epistemology of Mullâ Shadrâ illustrates a new trend in Islamic philosophy. Mullâ Shadrâ made various attempts to examine every philosophical view and argument ever known with regard to principles and methods. He then selects what he judges to be the best argument, reformulates it and finally tries to reconstruct a consistent system. The systematic philosophy is not peripatetic or illumination list, but a new reconstruction of both, which serves as a witness to the continuity of philosophical thought in Islam. That the Mullâ Shadrâ system is different from the emphasis on specific aspects of "rationality" as it is now does not mean that its founder understands it as "irrational" nor is it given to "mystical experience". But the system emphasizes a world view that intuitive vision is an inseparable part of knowledge. With this method, knowledge or wisdom is obtained not only that is generated by the power of reason but also through spiritual enlightenment, and all of that is then presented in rational form using rational arguments. For Mullâ Shadrâ, knowledge or wisdom is not only to enlighten cognition but also realization; change the form of the recipient of enlightenment itself and 
realize the knowledge gained so that the transformation of form occurs. All that cannot be achieved except by following the Shari'a, so a thought must hook the infant method in its system.

\section{References}

Abdullah, M. Amin. (2001) "al-Ta"wil al-Ilmi: kearah Perubahan Paradigma Penafsiran Kitab Suci”, dalam al-Jami'ah Journal of Islamic Studies IAIN Sunan Kalijaga Yogyakarta.

Amal, Taufik Adnan (ed.). (1987). Metode Alternatif Neomodernisme Islam Fazlur Rahman. Bandung: Mizan.

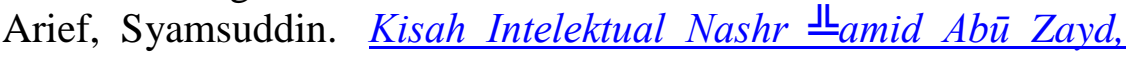
http://indrayogi.multiply.com/reviews/item/89, diakses 14Agustus 2010

al-Najdi, „Abd al-Raḥmān bin Muhammad bin Qāsim al-,Ashim, 1398 H. Majmū' Fatawa Syaykh al-Islām Ahmad bin Taymiyyah. tt: tpn.

al-Qa\|\| |an, Manna". (1973). Mabāłith fi 'Ulüm al-Qur'ān. Riyadh: Mansyurat al-,Ashr alHadis.

Dagun, Save. M. (1997). Kamus Besar Ilmu Pengetahuan. Jakarta: Lembaga Pengkajian Kebudayaan Nusantara (LPKN).

Ichwan, Moch Nur. (2003). Meretas Kesarjanaan Kritis al-Qur'an,Teori Hermeneutika Nashr Abū Zayd. Jakarta: Teraju.

Kaelan. (2005).MetodePenelitian Kualitatif bidang Filsafat.

Yogyakarta: Penerbit "Paradigma" Yogyakarta.

(1998).Filsafat Bahasa, Masalah dan Perkembangannya. Yogyakarta: Paradigma.

Kuntowijoyo. (2004). Islam Sebagai ilmu, Epistemologi, Metodologi, dan Etika. Bandung: Teraju Mizan.

Meuleman, Johan. (1994). "Pengantar", dalam Nalar Islami dan nalar Modern: Berbagai Tantangan dan Jalan Baru, Mohammed Arkoun; ter. Rahayu S. Hidayat. Jakarta: INIS.

Muhadjir, Noeng. (2006). Filsafat Ilmu, Kualitatif dan Kuantitatif untuk Pengembangan Ilmu dan Penelitian, Edisi III. Yogyakarta: Rake Sarasin. . (2006). Filsafat Ilmu, Kualitatif dan Kuantitatif untuk Pengembangan Ilmu dan Penelitian. Yogyakarta: Penerbit Rake Sarasin.

Mustaqim, Abdul and Sahiron Syamsudin (ed.). (2002). Studi al-Qur'an Kontemporer, Wacana Baru Berbagai Metodologi Tafsir. Yogyakarta: Tiara Wacana.

Mustofa, A. Filsafat Islam, (1999) Bandung: Pustaka Setia,

Nur, Syaifan. (2001) Filsafat Wujud Mulla Sadar, Yogyakarta: Pustaka Pelajat, -------------, Mulla Shadra. (2003): Pendiri Madzhab Al-Hikmah Al-Muta'aliyah, Jakarta: Teraju,

Nur Mufidah. (2006) Luk Luk, "Teosofi Transendental: Studi Pemikiran Mulla Shadra" dalam Episteme: Jurnal Pengembangan Ilmu Keislaman, Tulungagung: Pascasarjana STAIN,

Nashr, Seyyed Hosen, (2004) (edt), “Ensiklopedi Tematik Filsafat Islam” jilid II, Bandung: Mizan, , Shaliba, Jamil, Mu'jam Al-Falsafi, jilid 2

Supriyadi, Dedi. (2009) Pengantar Filsafat Islam Konsep, Filosof dan Ajarannya, Bandung: Pustaka Setia,

Wehr, Hans. (1974) A Dictionary Of Modern Written Arabic, Beirut: Maktabah Du Leban, 